\title{
BODIMO SOODGOVORNI ZA RAZVOJ
}

$\check{Z}$ Livimo $v$ času socialnih, ekonomskih in politicnih sprememb. Prebivalstvo se stara, okolje je onesnaženo, ponekod ga je prizadela prehitra urbanizacija, želimo si boljšega življenja. Mnogiv tem vidijo izziv za delovanje in učenje. Pri prebivalcih in posameznikih se pojavljajo tudi mnoge nove potrebe, na katere se ne moreta odzvati ne trg ne država s svojimi institucijami. Tudi vloga podjetij, ki so nekoč skrbela za izobraževanje delavcev in njihovo socialno varnost, se spreminja. Če je izobraževanje strateška naložba podjetja, potem labko za gotovo sklepamo, da podjetja svoje prihodnosti ne želijo ustvarjati z manj izobraženimi ljudmi, takšnimi, ki so potrebni temeljnega izobraževanja za življenje in delo.

Kako labko pomagamo tem manj izobraženim, da se bodo znašli v novih razmerah?

Nekateri so spremembam kos, drugi pa ne. Nekateri imajo posebne potrebe, ki so $v$ naglici spreminjanja zapostavliene. Nobena socialna skupina ne more pričakovati, da bo zanjo $v$ celoti poskrbela drža$v a$, ne da bi kaj storila sama zase in za druge. Odgovornost za zadovoljevanje potreb ljudi se začenja deliti na državo, lokalno oblast, lokalno skupnost in predvsem na liudi same.

V Evropi pomen države upada. Ta postaja čedalje subsidiarnejša, možnosti za razvoj prebivalstva išč lokalna skupnost sama. Rojevajo se lokalni projekti, ki naj izboljšajo življenje ljudi, jim pomagajo najti pot za nadaljnje izobraževanje, odpirajo nova delouna mesta za tiste, $k i$ jih je odmirajoča industrija potisnila na rob itd. Pri tem se brezposelni v kraju vključujejo $v$ lokalne projekte, tam delajo in se učijo. Vendar se ne le preusposabliajo! Izkazalo se je, da to
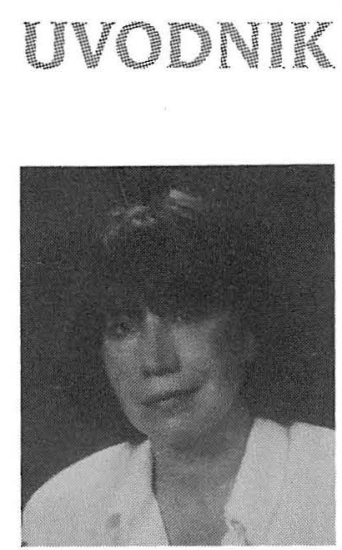

Dušana

Findeisen ni rešitev. Rešitev je v vključevanju manj izobraženih in brezposelnih v sistem lokalne kulture, lokalne tradicije in $v$ vizijo razvoja kraja.

In vendar! Kako si zamišljamo razvoj svojega kraja? Ali imamo vsaj približno predstavo, kakšen naj bi bil ta kraj čez dvajset let? Ali vemo, kateremu gospodarskemu sektorju bomo $v$ pribodnje dali prednost in zakaj? Pa tudi to, kdo so bistveni nosilci razvoja v kraju, ki jih moramo povezati, da bi uresničili skupno vizijo? Podjetja, ustanove, društva, prebivalci sami, lokalna oblast in navsezadnje država?

Razvoj ljudi in kraja ni nekaj, kar bi lebdelo $v$ zraku. Začne se zljudmi, ki tam živijo. Ti imajo svoje upanje, načrte, strahove, skrbi, znanje in izkušnje, svojo preteklost. Če jim bomo pomagali prepoznati njihove potrebe, združiti se v skupine, oblikovati cilje in ukrepe $v$ zvezi z lokalnimi projekti, č jim bomo pomagali, da se bodo naucili javnega nastopanja in pogajanja z oblastmi, $k$ oblikovanju zavesti - da vedo, imajo pravico vedeti in tudi pravico, da jim drugi prislubnejo, če si bodo z nami pridobili dodatno znanje in večjo samostojnost, bodo imeli tudi večji vpliv: ekonomski, socialen, političen in psibološki. Tudi mi smo soodgovorni za njibov in s tem tudi za naš razvoj.

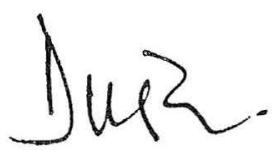

